Military Technical College Kobry El-Kobbah, Cairo, Egypt

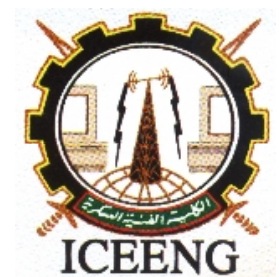

\section{$8^{\text {th }}$ International Conference on Electrical Engineering ICEENG 2012}

\title{
Photovoltaic power system based on MPP tracking technique to feed radar stations
}

\author{
By \\ Hassan. H. El-Tamaly* \\ Hassan Abd-El-Aliem**
}

\section{$\underline{\text { Abstract: }}$}

The photovoltaic power system, PVPS, converts the solar radiation directly to electricity without fuel, moving parts, noise and greenhouse gases emission then it's a clean and environmentally friend power system .

This paper introduces a complete design of PVPS based on energy balance condition, EB , and maximum power points, MPPs, tracking technique to feed the simulated load in an Egyptian remote site ,Marsa-Alam. This load consists of four radar stations, automatic command center, manual command center , communication center, charging center and lighting for the radar battalion. Also, the design parameters obtained by applying the EB have been compared with the design parameters obtained by using the MPPs tracking technique. A new computer Matlab Program has been designed and operated to determine the hourly MPP through the daily day time along the year.

\section{Keywords:}

Photovoltaic, power system, maximum power points tracking technique, energy balance condition, utility grid and solar cells module

* Professor of Electrical power engineering, Vice Dean for Community Service and Environment Development, Faculty of Engineering, Minia University, Minia, Egypt, dr_h_tamaly@yahoo.com

** Brigadier retired engineer air defense, Egyptian Armed Forces, Teacher Assistant, Higher Thebes Institute for Engineering, Thebes Academy, Cairo, Egypt, Hassan_June_1955@yahoo.com 


\section{Introduction:}

The electric energy is the one of the important indices of the development at any site. In the last years the demand on the electric energy is increased. In the same time the traditional sources for generating the electric energy (Fossil fuel) are decreasing continuously with the time and the reserve of the fossil fuel is decreased, also the price of fossil fuel is increased quickly.

The results are decreasing the generating energy now and followed by increasing the $\mathrm{kWh}$ price and the generation of the electric energy using the fossil fuel may be off at the long run. The prevision of the electric energy for any remote area from utility grid, U.G, is more expensive because the costs of over head transmission lines or cables and the distribution stations between the U.G and the equipments in the remote area are high. The diesel generator units are the sole source for generating electric energy in the remote areas, but they have many disadvantages as the high cost of fuel consumption, greenhouse gases emission, and noise according to the moving parts, cost of repairing and spare parts (technical supporting) and low part load efficiency. The renewable energy sources for generating electrical energy (solar, wind, water, fuel cells...) are the most alternative sources instead of the fossil fuel sources especially for feeding the loads in the remote area. They are clean and environmentally friends electric energy sources. The photovoltaic power system, PVPS, converts the solar radiation directly to electricity without fuel, moving parts, noise and greenhouse gases emission and is a clean and environmentally friend power system.

\section{Problem Statement:}

Marsa-Alam is important, promising tourism and nice weather site (has long sun chine time), [1], The existing of the radar battalion here save the detection of any air target enter to it, gives alarm to higher command centers to take the suitable decision toward this target (friend or enemy and destroying by air forces or air defense forces if it is enemy) and by this the protection for Marsa-Alam and its international airport will be saved and this pulls more visitors and increases the input of the tourism and also increases the Egyptian national input. Marsa- Alam has a latitude $\varphi=25^{\circ} 5^{\prime} \quad 0^{\prime \prime}$ $\mathrm{N}$ and Longitude of $34^{\circ} 5^{\prime} 4 \mathrm{o}^{\prime \prime} \mathrm{E}$. The radar battalion situated in this site consists of four radar stations. These radar stations detecting any air target in the daytime or night period and giving the coordinates $(h, \varepsilon, \beta, r)$ of the target to the command centers.

The load of the four radar station under study can be described as follows:

1) R1 has 3 diesel generators each of them is $60 \mathrm{~kW}, 3 \varnothing, 220 \mathrm{~V}$ and $50 \mathrm{HZ}$. One of them is the main generator and the others are reserve. The actual consumed power is $28 \mathrm{~kW}$. 
2) R2 has 3 Diesel generators each of them is $30 \mathrm{~kW}, 3 \emptyset, 220 \mathrm{~V}$ and $50 \mathrm{HZ}$. One generator is the main and the others are reserve. The actual consumed power is $12 \mathrm{~kW}$

3) R3 has 3 Diesel generators each of them is $30 \mathrm{~kW}, 3 \emptyset, 220 \mathrm{~V}$ and $50 \mathrm{HZ}$. One generator is the main and the others are reserve. The actual consumed power is $12 \mathrm{~kW}$

4) R4 has 2 Diesel generators each of them is $25 \mathrm{~kW}, 3 \emptyset, 220 \mathrm{~V}$ and $50 \mathrm{HZ}$. One generator is the main and the others are reserve. The actual consumed power is $12 \mathrm{~kW}$

Also there is another load represented by:

1) Automatic command center has 2 diesel generators each of them is $100 \mathrm{~kW}$, $3 \emptyset, 220 \mathrm{~V}$ and $50 \mathrm{HZ}$. One generator is the main and the others are reserve.

2) Manual command center needs $10 \mathrm{~kW}$.

3) Communication center needs $5 \mathrm{~kW}$.

4) Charging center needs $5 \mathrm{~kW}$.

5) Lighting needs $50 \mathrm{~kW}$.

The Radar Battalion operates in Maximum case and the power required is $100 \%$. Figure (1) shows the daily load curve of the load demand.

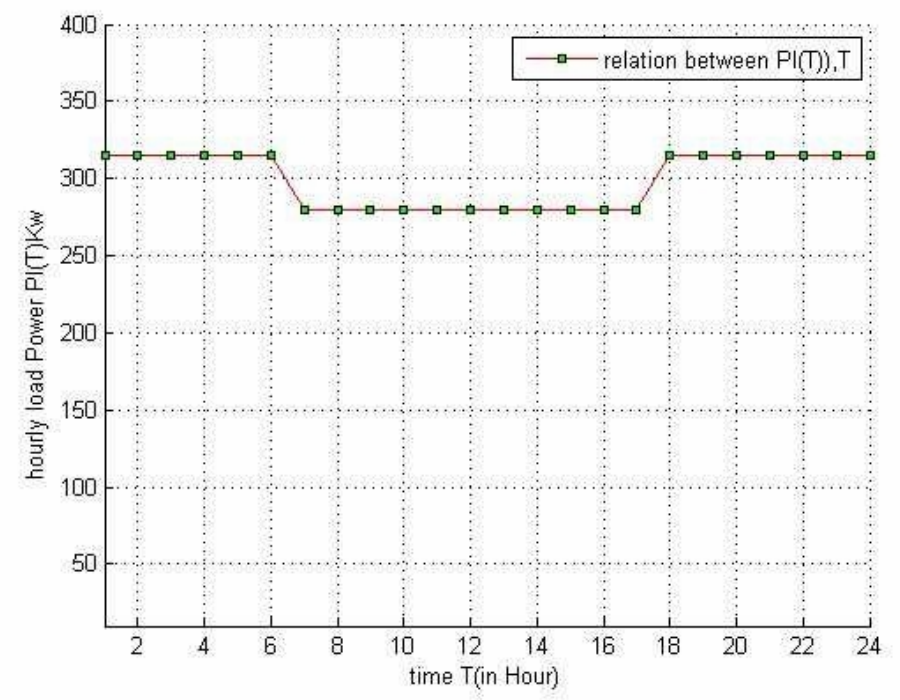

Figure (1): the daily load curve of the Load demand

The diesel generators which used to feed the above load have some problems in its fuel and maintenance and so on. For this reason it is recommended here to use the photovoltaic solar cells to feed the above load instead of the diesel engines where the Marsa- Alam site has a lot of solar radiation through the year seasons.

\section{Design the Photovoltaic System Based on MPP}

3.1Determination of PVPS design construction using Energy Balance Method. 3.1.1 Data required.

A. The solar hourly radiation incidents on the horizontal of Marsa - Alam site has been taken from the Metrological Authority of Egypt, [2]. Then this hourly 
radiation has been calculated to be on surfaces tilted by the monthly best tilt angle using the equation in reference [3] of:

$S=\varphi-\delta$

Table (1) shows the monthly best tilt angle. Then the radiation on the tilted surfaces has been calculated by using the equations in ref [4]. Figure (2) displays the hourly radiation of Marsa-Alam on the tilted surfaces for the four year seasons.

Table (1) the monthly best tilt angle of Marsa-Alam of $\varphi=25^{\circ} 5^{\prime} \quad o^{\prime \prime} N$
\begin{tabular}{|c|c|c|}
\hline Month & $\mathbf{\delta}^{\mathbf{0}}$ & $\mathbf{S}^{\mathbf{0}}$ \\
\hline \hline January & -20.92 & 45.92 \\
\hline February & -12.95 & 37.95 \\
\hline March & -2.42 & 27.42 \\
\hline April & 9.41 & 15.59 \\
\hline May & 18.79 & 6.21 \\
\hline June & 23.09 & 1.91 \\
\hline July & 21.18 & 3.82 \\
\hline August & 13.46 & 11.55 \\
\hline September & 2.22 & 22.78 \\
\hline October & -9.6 & 34.6 \\
\hline November & -18.91 & 43.91 \\
\hline December & -23.05 & 48.05 \\
\hline
\end{tabular}

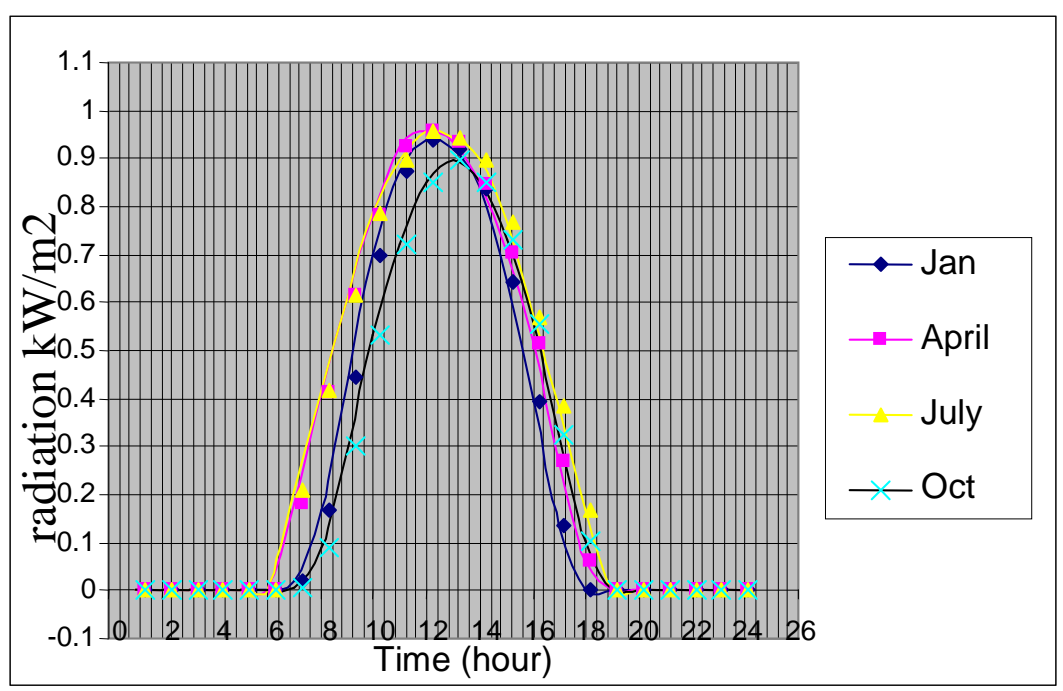

Figure (2): the hourly radiation $\left(\mathrm{kW} / \mathrm{m}^{2}\right)$ of Marsa-Alam on the tilted surfaces for the four year seasons summer (July), autumn (Oct), winter (Jan), spring (Apr).

B. The ambient temperatures of Marsa - Alam site are shown in Table (2), [2]. 
Proceedings of the $\boldsymbol{8}^{\text {th }}$ ICEENG Conference, 29-31 May, 2012

Table (2): The ambient temperature of the selected site

\begin{tabular}{|c|c|c|}
\hline Month & Max. $^{\text {}} \mathbf{C}$ & Min. ${ }^{\mathbf{}} \mathbf{C}$ \\
\hline 17 January & 21.1 & 14.4 \\
\hline 16 February & 20.6 & 14.3 \\
\hline 16 March & 20.1 & 13.4 \\
\hline 15 April & 25.2 & 16.8 \\
\hline 15 May & 32.6 & 22.1 \\
\hline 11 June & 38.2 & 30.9 \\
\hline 17 July & 33.4 & 27.1 \\
\hline 16 August & 34.6 & 27.7 \\
\hline 15 September & 32.9 & 27.2 \\
\hline 15 October & 29.4 & 22.5 \\
\hline 14 November & 25.4 & 18.6 \\
\hline 10 December & 22.6 & 16.4 \\
\hline
\end{tabular}

C. The solar cells Module type of FVG - 185M-MC, [5], has been selected for this study. The characteristics of this solar cell Module type are displayed in Table (3).

Table (3): the characteristics of the selected solar cell Module type.

\begin{tabular}{||l|l||}
\hline Item & \multicolumn{1}{|c|}{ FVG 185M-MC [5] } \\
\hline Module efficiency & $14.60 \%$ \\
\hline Cell efficiency & $17.50 \%$ \\
\hline Maximum power (Pm) & $185(\mathrm{w})$ \\
\hline Voltage at pm (Vmp) & $37.50 \mathrm{Vdc}$ \\
\hline Current at pm ( Imp) & $4.90 \mathrm{~A}$ \\
\hline Short-circuit current (Isc) & $5.40 \mathrm{~A}$ \\
\hline Open-circuit voltage (Voc) & $44.5 \mathrm{Vdc}$ \\
\hline Temperature coefficient of Isc & $(2.7 \pm 0.5) \mathrm{mA} /{ }^{\circ} \mathrm{C}$ \\
\hline Temperature coefficient of Voc & $-(150 \pm 10) \mathrm{mV} /{ }^{\circ} \mathrm{C}$ \\
\hline Temperature coefficient of Pm & $-(0.43 \%) /{ }^{\circ} \mathrm{C}$ \\
\hline Nominal operating cell temp (Noct) & $47 \pm 2{ }^{\circ} \mathrm{C}$ \\
\hline Maximum-system voltage (VDC) & $700 \mathrm{Vdc}$ \\
\hline Dimensions, m & $1.581 \times 0.809$ \\
\hline Area, ${ }^{2}$ & $1.279029 \mathrm{~m}^{2}$ \\
\hline Cell Temp (Tc) & $25^{\circ} \mathrm{C}$ \\
\hline Cells and number & Mono-crystal line silicon -72 cell \\
\hline Maximum series fuse rating & $7 \mathrm{~A}$ \\
\hline
\end{tabular}


D. Table (4) reveals characteristics of the selected DC-AC Inverter.

Table (4): The characteristics of the selected inverter unit

\begin{tabular}{|l|l|}
\hline Item & Grid Tie Inverter GT- 100E,[6]. \\
\hline Continuous power rating & $100 \mathrm{KW}$ AC \\
\hline Nominal DC power rating & $105 \mathrm{KW} \mathrm{DC}$ \\
\hline Nominal AC voltage & $400 \mathrm{VAC}$ three phase \\
\hline Nominal AC frequency & $50 \mathrm{~Hz}$ \\
\hline Line power factor & $>0.99$ above $20 \%$ rated power \\
\hline Maximum Ac line current & $164 \mathrm{amp}$ Ac \\
\hline AC current distortion & $<3 \%$ THD at rated power \\
\hline Max open circuit voltage & $650 \mathrm{VDC}$ \\
\hline Power tracking windows range & 300 to $600 \mathrm{VDC}$ \\
\hline Max DC input current & 319 amp DC \\
\hline Peak inverter efficiency & $95.5 \%$ \\
\hline Average input DC voltage & $(300+600) / 2=450 \mathrm{VDC}$ \\
\hline Average input DC current & $(100 * 1000) / 450=222.22 \mathrm{~A}$ \\
\hline Ambient temperature range & $-10^{\circ} \mathrm{C}$ to $+45^{\circ} \mathrm{C}$ \\
\hline
\end{tabular}

\subsubsection{Estimation the PVPS Construction, [3].}

The Size of solar cells required to feed the load under study has been determined by using the Energy Balance method, [3]. Table (5) display the construction of the designed PVPS using the selected types of PV module and Inverter unite.

Table (5): The construction of the designed PVPS using the selected types of PV module and inverter unit.

\begin{tabular}{|l|l|}
\hline \multicolumn{1}{|c|}{ Item } & \multicolumn{1}{c|}{ Requirements } \\
\hline \hline Type of PV module. & FVG 185 M- MC, [5]. \\
\hline Type of inverter unit. & Grid Tie inverter GT-100 E,[6]. \\
\hline Module active area, $\mathrm{m}^{2}$. & $1.279029 \mathrm{~m}^{2}$ \\
\hline Optimum Solar Cells Area, OSCA, $\mathrm{m}^{2}$. & $9750.00 \mathrm{~m}^{2}$ \\
\hline Number of series modules/string, Ns. & 12 module \\
\hline Number of parallel string/subsystem, Np. & 45 string \\
\hline $\begin{array}{l}\text { Number of modules / subsystem, Nt }= \\
\text { Ns* Np. }\end{array}$ & 540 Module \\
\hline Number of subsystems & 14 subsystems \\
\hline Number of inverter units, INU. & 14 INU \\
\hline Solar cell area of one subsystem, SOSCA & $690.67566 \mathrm{~m}^{2}$ \\
\hline Optimum number of modules, ONpv & 7623 Module or $14 \times 540=7560$ \\
\hline
\end{tabular}


Without MPPT:

- The Total Yearly Energy of the Load, (TYEPL) is as following: TYEPL $=7175 \mathrm{kWh} * 365=2618875.00 \mathrm{kWh}$.

- The Total Yearly Energy of the PV output, (TYEPV) is as following: TYEPV $=86183.539(\mathrm{kWh}) * 30.4=2619979.586(\mathrm{kWh})$.

- OSCA= $9750\left(\mathrm{~m}^{2}\right)$.

- $\operatorname{SOSCA}=690.675\left(\mathrm{~m}^{2}\right)=691\left(\mathrm{~m}^{2}\right)$.

- Number of subsystems $=$ number of INU $=14$.

- Number of modules /subsystem $=12 * 45=540$ modules.

- Total number of modules in PVPS $=14 * 540=7560$ modules.

Figure (3) shows the configuration of one subsystem.

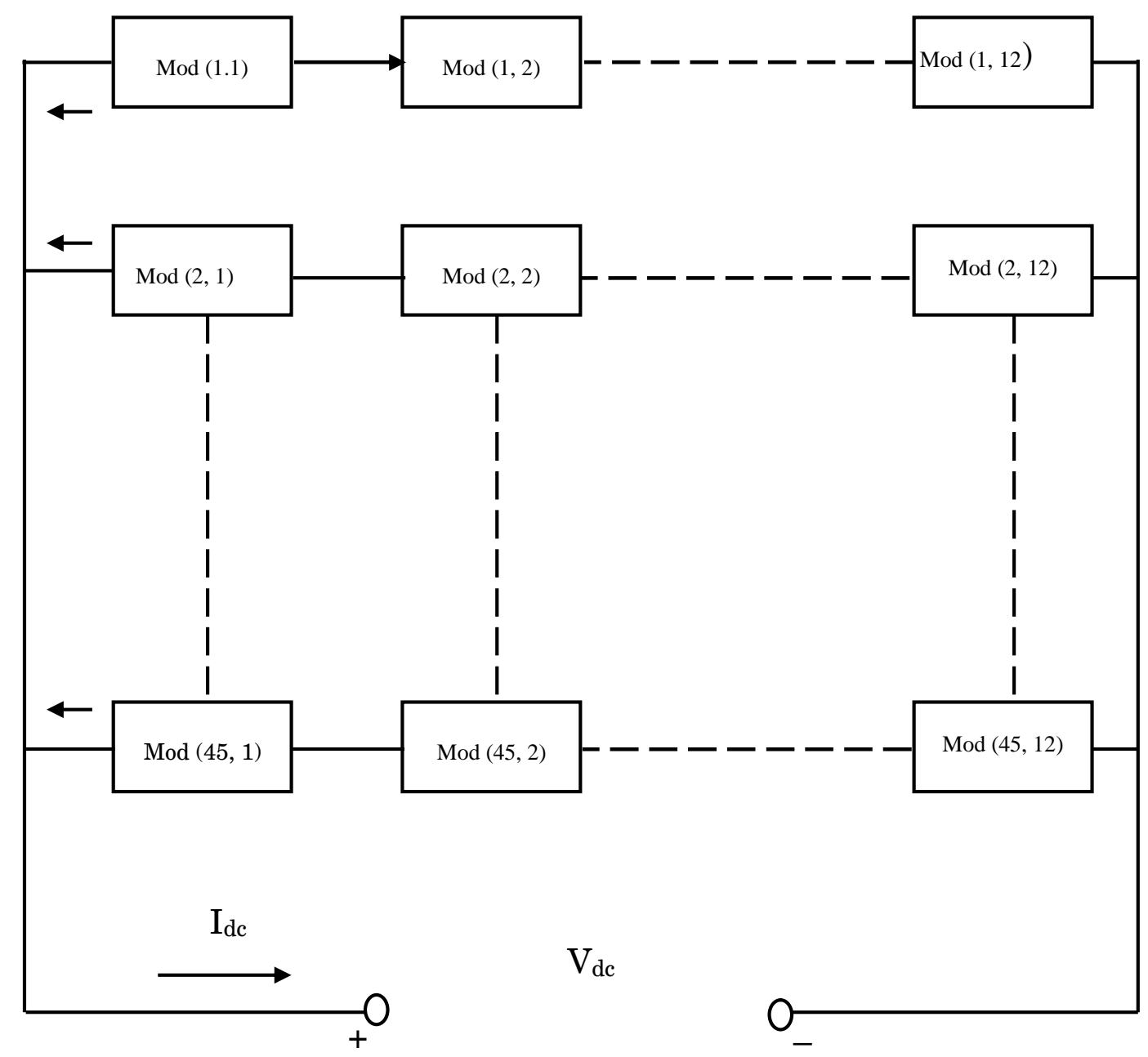

Figure (3): the configuration of one subsystem.

The one subsystem has the following data:

- $\operatorname{Imp}=45 \times 4.9(\mathrm{ADC})=222.222(\mathrm{ADC})=\mathrm{Idc}$

- $\mathrm{Vmp}=12 \times 37.5(\mathrm{VDC})=450(\mathrm{VDC})=\mathrm{V}_{\mathrm{dc}}$

- $\mathrm{Isc}=45 \times 5.40(\mathrm{ADC})=243(\mathrm{ADC})$

- $\mathrm{Voc}=12 \times 44.5(\mathrm{VDC})=534(\mathrm{VDC})$

- $\mathrm{Pmp}=450 \times 222.222=100 \mathrm{~kW}$ DC $=\mathrm{Pdc}_{\mathrm{dc}}$ 


\section{3-2. Determination of PVPS Construction Based on MPP.}

The equivalent electrical circuit describing the solar cells module or array used in the analysis is shown in Fig (4), [7]. The circuit consists of a light-dependent current source, $I_{L}$ or $I_{p h}$, an internal shunt resistance, $R_{s h}$, with very high value and series resistance, $R_{\mathrm{s}}$, with value as low as possible, so that most of the available current, I, can be delivered to the load.

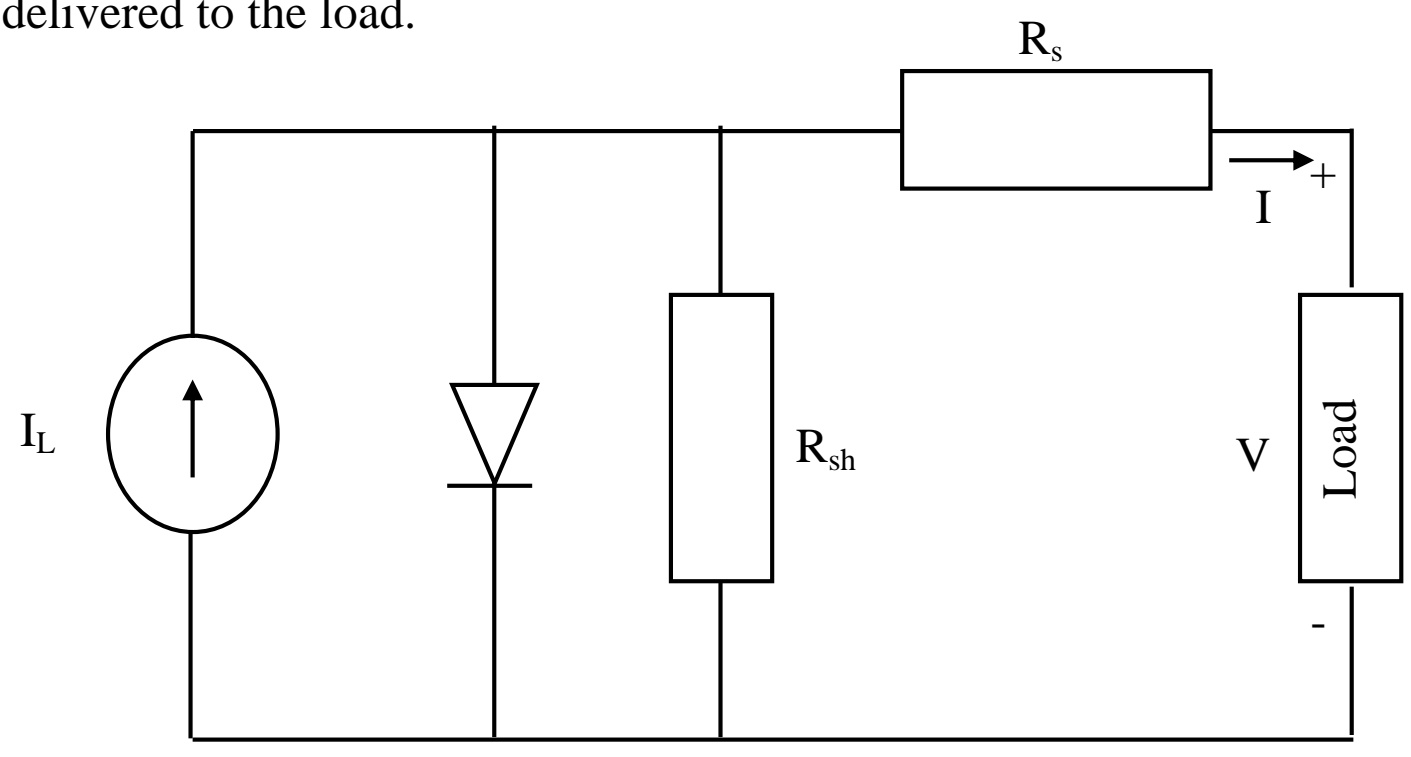

Figure (4): Equivalent circuit for a solar cells module or array

The module or array equivalent circuit output current, I, as a function of output voltage, $\mathrm{V}$, as follows [8]:

$$
\begin{aligned}
& \mathrm{I}(\mathrm{v})=\mathrm{I}_{\mathrm{sc}}\left\{1-\mathrm{C}_{1}\left[\exp \left(\frac{\mathrm{V}+\Delta \mathrm{V}}{\mathrm{C} 2 \mathrm{~V}_{\mathrm{oc}}}\right)-1\right]\right\}+\Delta \mathrm{I} \\
& \mathrm{C}_{2}=\frac{(\mathrm{Vmp} / \mathrm{Voc})-1}{\mathrm{In}\left(1-\left(\mathrm{I}_{\mathrm{mp}} / \mathrm{I}_{\mathrm{sc}}\right)\right)} \\
& \mathrm{C}_{1}=\left(1-\left(\mathrm{I}_{\mathrm{mp}} / \mathrm{I}_{\mathrm{sc}}\right)\right) * \exp \left[-\mathrm{V}_{\mathrm{mp}} /\left(\mathrm{C}_{2} * \mathrm{~V}_{\mathrm{oc}}\right)\right] \\
& \mathrm{T}=\mathrm{TA}+\mathrm{q}^{*} \mathrm{H}_{\mathrm{T}} \\
& \mathrm{T}=\mathrm{T}-\mathrm{T}_{\mathrm{ref}} \\
& \Delta \mathrm{I}=\alpha\left(\mathrm{H}_{\mathrm{T}} / \mathrm{H}_{\mathrm{ref}}\right) * \Delta \mathrm{T}+\left(\left(\mathrm{H}_{\mathrm{T}} / \mathrm{H}_{\mathrm{ref}}\right)-1\right) * \mathrm{I}_{\mathrm{sc}} \\
& \Delta \mathrm{V}=-\beta_{1} * \Delta \mathrm{T}-\mathrm{R}_{\mathrm{s}} * \Delta \mathrm{I} \\
& R_{s}=\frac{V_{o c}-V_{m p}}{I_{m p}} .
\end{aligned}
$$


$\mathbf{R}_{1=} \mathbf{V}_{\mathbf{m p}} / \mathbf{I}_{\mathbf{m p}}$

A MTLAB computer program has been designed to determine the hourly maximum power point and its power for the PVPS.

Figure (5) shows the flowchart of this program. The input data required to the program are:

(a) The characteristics of the selected solar cells module (one subsystem) which can be rewritten from subsubitem (3-1-2) as follows:

$$
\begin{aligned}
& \mathbf{V}_{\mathrm{mp}}=450 \mathrm{~V}, \mathbf{V o c}=534 \mathrm{~V}, \mathbf{I}_{\mathrm{mp}}=222.222 \mathrm{~A}, \mathbf{I}_{\mathrm{sc}}=243 \mathrm{~A}, \\
& \mathrm{R}_{\mathrm{s}}=0.38 \quad \text { at Standard Test Condition }(\mathrm{STC})
\end{aligned}
$$

(b) From Table (3) it is found that:

$$
\alpha=0.003 \mathrm{~A} /{ }^{\circ} \mathrm{C}, \beta_{1}=-0.15 \mathrm{~V} /{ }^{\circ} \mathrm{C}
$$$$
\mathrm{q}=0.03
$$

$\mathrm{R}_{\mathrm{L}}=2.03$

(c) The ambient temperatures of the selected site $\mathrm{T}_{\mathrm{A}}$ which are displayed in Table (2).

(d) The hourly solar radiation which incidents on the tilted surface, Fig (2).

The program outputs are $\mathbf{I}_{\mathrm{mp}}, \mathbf{V}_{\mathrm{mp}}$ and $\mathbf{P}_{\mathrm{mp}}$ in each hour from 7 to 18 for each month from January to December. 
Proceedings of the $\boldsymbol{8}^{\text {th }}$ ICEENG Conference, 29-31 May, 2012

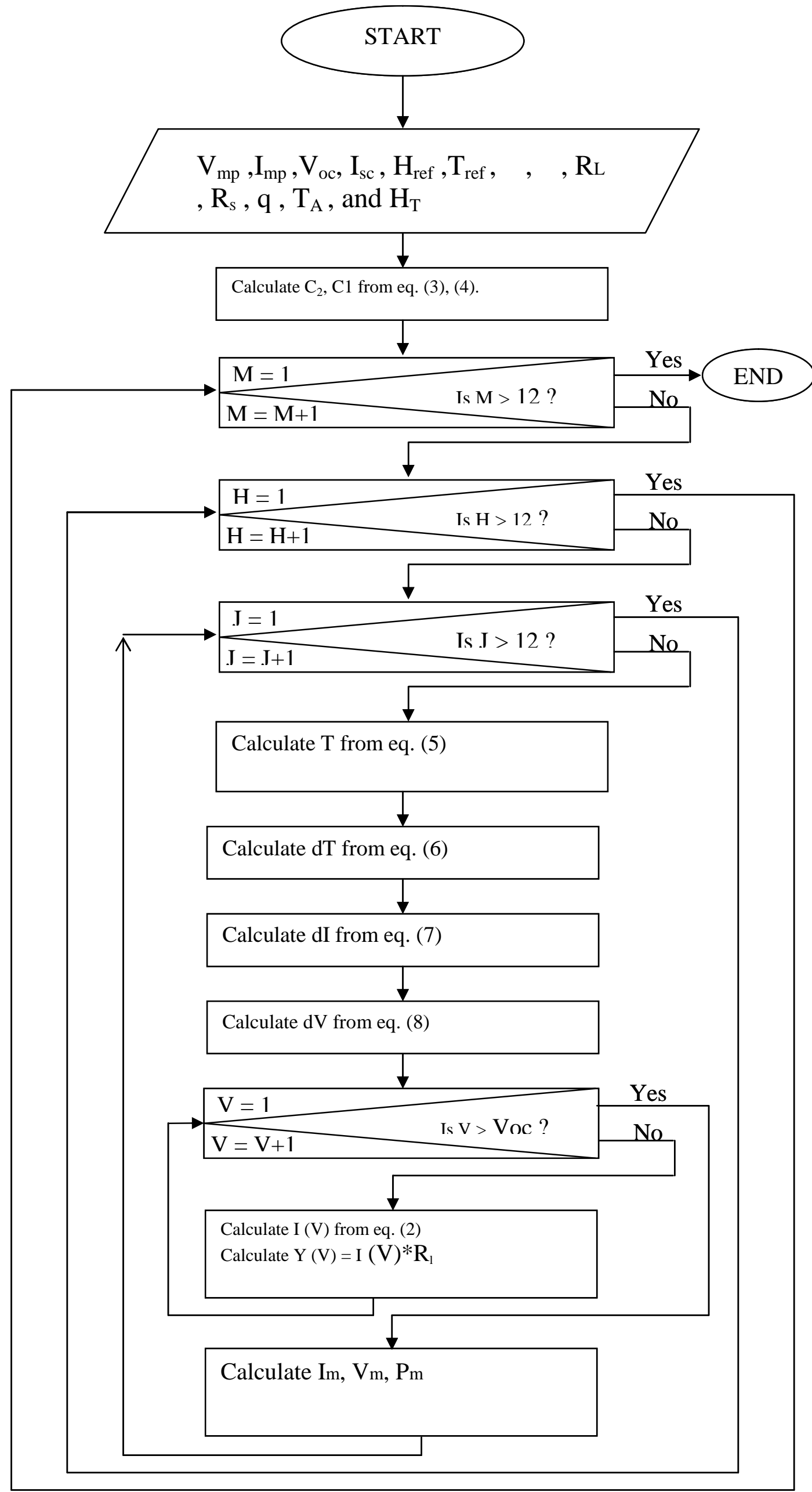


Figure (5): The flowchart of the program designed to determine the maximum power point and its power for the PVPS.

Table (6) shows the total monthly PVPS output power, load power, surplus power and deficit power $(\mathrm{kWh})$ for Jan to December with and without MPPT.

Table (6): Total Monthly PVPS output power, Load power, surplus power and deficit power $(k W h)$, with and without MPPT

\begin{tabular}{|c|c|c|c|c|c|c|c|}
\hline \multirow[b]{2}{*}{ Month } & \multicolumn{3}{|c|}{ With MPPT } & & \multicolumn{3}{|c|}{ without MPPT } \\
\hline & $\begin{array}{l}\text { Pvo(t) } \\
\text { (kWh) }\end{array}$ & $\begin{array}{c}\text { surplus } \\
(\mathbf{k W h})\end{array}$ & $\begin{array}{c}\text { Deficit } \\
\text { (kW) }\end{array}$ & $\begin{array}{c}\mathbf{P l}(\mathbf{t}) \\
(\mathbf{k W h})\end{array}$ & $\begin{array}{l}\text { Pvo(t) } \\
\text { (kWh) }\end{array}$ & $\begin{array}{c}\text { surplus } \\
(\mathbf{k W h})\end{array}$ & $\begin{array}{c}\text { Deficit } \\
\text { (kW) }\end{array}$ \\
\hline Jan & 7503.785 & 5209.508 & 48880.723 & 7175 & 65545.617 & 3958.017 & $\overline{4587.40}$ \\
\hline Feb & 9562.257 & 7127.73 & 4740.473 & 7175 & 7629.042 & 4792.442 & 4338.40 \\
\hline Mar & \begin{tabular}{|l|}
10276.274 \\
\end{tabular} & 7695.605 & \begin{tabular}{|l|l|}
4594.331 \\
\end{tabular} & 7175 & 7895.456 & 4936.566 & 4216.110 \\
\hline Apr & 9042 & 6339 & 4471.833 & 7175 & 7588.132 & 4.008 & 876 \\
\hline May & 8956 & 615 & 4375.677 & 7175 & 734 & 929 & 753 \\
\hline Jun & 9123.269 & \begin{tabular}{|l|l}
6296.723 \\
\end{tabular} & 4348.454 & 7175 & 7166.908 & \begin{tabular}{|l|l|}
4016.874 \\
\end{tabular} & 4024.966 \\
\hline July & 9561 & 6673.712 & 4287.275 & 7175 & 7598.318 & 4423.551 & 4000.228 \\
\hline Aug & 8548.752 & \begin{tabular}{|l|}
5815.051 \\
\end{tabular} & \begin{tabular}{|l|l|}
441.299 \\
\end{tabular} & 7175 & 7141 & .575 & 4097.64 \\
\hline Sep & 8202.564 & 5624.455 & 4596.892 & 7175 & 6758.042 & 3859.643 & 4276.601 \\
\hline Oct & 6892.345 & 4568.77 & 4851.425 & 7175 & 611 & 3395.329 & 4451.791 \\
\hline Nov & 9765.161 & 7371.942 & 4781.782 & 7175 & 7375.593 & 4692.839 & 4492.241 \\
\hline Dec & 8776.271 & 6485.954 & 4884.683 & 7175 & 7020.782 & 4375.732 & 4529.950 \\
\hline$\sum$ & 06210.825 & 75365.677 & 5254.847 & 86100 & 86183.539 & 51236.505 & 51152.956 \\
\hline
\end{tabular}

From the table (6) and the previous parameters it can be seen that:

With MPPT:

- $\quad$ TYEPV $=106210.825 \times 30.4=3228809.08(\mathrm{kWh})$

Then

TYEPV (with MPPT)

3228809.08

- $\overline{\text { TYEPV (without MPPT) }}=\overline{2619979.586}=1.23$

- $\quad \therefore \mathrm{OSCA}=\frac{9750}{1.23}=7926.83 \cong 7927\left(\mathrm{~m}^{2}\right)$

- $\quad$ Number of subsystems $=\frac{7927}{691}=11.47 \cong 11$ subsys

- $\quad$ Number of subsystem $=$ Number of DC/DC converters $=$ Number of DC/AC inverters = Number of $100 \mathrm{~kW}$ Ac $3 \emptyset 400 / 220 \mathrm{~V} 50 \mathrm{~Hz}$ transformers $=11$.

- Total Number Modules in PVPS $=11 \times 540=5940$ Modules

From the previous the system with MPPs Tracking technique is desirable where the MPPT technique saves: 
- The area $=9750-7927=1823\left(\mathrm{~m}^{2}\right)$

- $\mathrm{DC} / \mathrm{DC}$ converters $=3$ units

- $\mathrm{DC} / \mathrm{AC}$ inverters $=3$ units

- $100 \mathrm{~kW}$ Ac $3 \varnothing 400 / 220 \mathrm{~V}-50 \mathrm{~Hz}$ trans $=3$ unit

- Modules $=3 \times 540=1620$ modules

- Finally the total costs can be reduced by $\left(1-\frac{11}{14}\right) \times \frac{100}{100}=21.43 \%$

But if we stay using the PVPS with MPPT and with the same OSCA $(9750 \mathrm{~m} 2)$ to generate TYEPV $=3228809.08 \mathrm{kWh}$.

Then the excess energy is equal to:

$3228809.08-2619979.586=608829.494 \mathrm{kWh} /$ year.

This excess energy can be used for generating more hydrogen gas from sea water Via electrolysis processing and used as a fuel for the fuel-cells power systems (FCPS) with the air to generate electric energy feeded to the load during the night time or in the case of deficit in the output of the PVPS, Figure (6) Shows the power from PVPS at each hour from 7 to $18(1-12)$ for Jan with and without MPP.

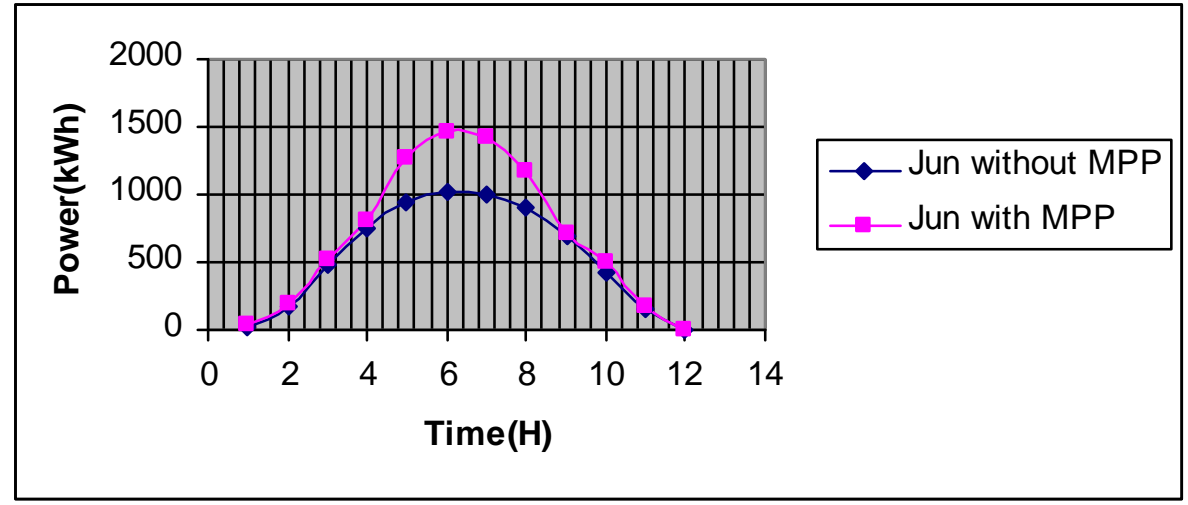

Figure (6): the power from PVPS at each hour from 7 to 18 (1-12) for Jan with and without MPP.

\section{Conclusions:}

This paper presents a new proposed method based on MPP tracking system. This method was computerized by A MATLAB computer program. This method with its computer program can be used to estimate the design parameters for a stand alone photovoltaic power system to be installed at any site in the world. This method was applied to determine the design parameters of a stand - alone photovoltaic power system to be installed at Marsa- alam site as an Egyptian remote site to feed a load of a radar station and its accessories. By comparing the design parameters which found with the design parameters which obtained by applying the energy balance method for the same system it is found that:

1. The solar cells area decreased with $18.7 \%$ with respect to the results of applying energy balance method 
2. The cost decreased with $21.43 \%$ with respect to the results of applying energy balance method

\section{References:}

[1] http://www.holiday-weather.com /marsa_Alm/averages/.

[2] Meteorological Authority of Arab Republic of Egypt, 2007.

[3] H. H. EL-Tamaly and F. M. EL-Kady, optimizing the integration of Photovoltaic/wind system with Electric utility, proceeding on Al-Azhar Engineering six international conference, p.69-80, September 2000.

[4] S. A. Klein, calculation of the Monthly Average insulation on the tilted surface, solar energy, vol. 19, p. 325-329, 1977.

[5] http://www.fvgenergy.com /photovoltaic-eng/ photovoltaic-module-160185 w-eng.html.

[6] http://www.renewpowers.com/GT-100E.html.

[7] Kyoung.Ro, Two-Loop controller for maximizing performance of a Grid - connected photovoltaic- fuel cell Hybrid power Plant, thesis, Blacksburg, Virginia April 1997.

[8] Bogdan S. orowy and Z. M. salameh, Methodology for optimally sizing the combination of Battery bank and PV array in a Wind/PV hybrid system, IEEE Transactions on energy conversion, Vol .11, No. 2, p. 367-375, June 1996.

\section{Nomenclatures:}

h: High or Altitude of the air target $(\mathrm{km})$.

r: $\quad$ Slop range of the air target $(\mathrm{km})$.

$\varepsilon$ : $\quad$ Elevation angle of the air target $\left(\mathrm{o}-90^{\circ}\right.$ in vertical plane).

$\beta$ : $\quad$ Azimuth angle of the air target $\left(\mathrm{o}-360^{\circ}\right.$ in horizontal plane $)$.

S: The monthly best tilt angle of solar cell modules or PV array, degrees,

$\varphi: \quad$ The site latitude for the location, degrees.

$\delta$ : $\quad$ Sun's declination angle, degrees, ranges between $+/-23.45^{\circ}$.

I : $\quad$ Module or array output current, (Amps),

V: Module or array output voltage, (volts),

$\mathrm{I}_{\mathrm{mp}}$ : Module or array maximum power current, (Amps),

$\mathrm{V}_{\mathrm{mp}}$ : Module or array maximum power voltage, (volts),

$\mathrm{V}_{\mathrm{oc}}$ : Module or array open circuit voltage, (volts),

$\mathrm{I}_{\mathrm{sc}}$ : Module or array short circuit current, (Amps).

HT: Tilted radiation, $(\mathrm{kWh})$.

$\mathrm{H}_{\text {ref: }}$ Reference radiation, $(\mathrm{kWh})$

$\mathrm{R}_{\mathrm{s}}$ : $\quad$ Module or array series resistance, (ohms),

$\mathrm{T}$ : $\quad$ Cell temperature, $\left({ }^{\circ} \mathrm{C}\right)$,

$\mathrm{T}_{\mathrm{A}}$ : Ambient temperature, $\left({ }^{\circ} \mathrm{C}\right)$,

$\mathrm{T}_{\text {ref: }}$ Reference temperature, $\left({ }^{\circ} \mathrm{C}\right)$, 
Proceedings of the $\boldsymbol{8}^{\text {th }}$ ICEENG Conference, 29-31 May, 2012

$\Delta \mathrm{T}$ : Change in cell temperature, $\left({ }^{\circ} \mathrm{C}\right)$,

q: $\quad$ Cell thermal resistance, $\left(\mathrm{m}^{2} .{ }^{\circ} \mathrm{C} / \mathrm{kW}\right)$,

$\alpha$ : Current change temperature coefficient at reference radiation, $\left(\mathrm{Amp} /{ }^{\circ} \mathrm{C}\right)$.

$\beta_{1}$ : Voltage change temperature coefficient at reference radiation, (volts $/{ }^{\circ} \mathrm{C}$ ).

$\mathrm{R}_{1}$ : Load resistance, ohm. 